\title{
Ovarian interstitial tissue of the wood mouse, Apodemus sylvaticus
}

\author{
F. A. Brook* and J. R. Clarke† \\ Department of Agricultural Science, Oxford University, Parks Road, Oxford OX1 3PF, UK
}

\begin{abstract}
Summary. The ovary of the wood mouse contains an unusually large amount of interstitital tissue which appears to develop from undifferentiated cells of the ovarian stroma and also by transformation of theca or granulosa cells of atretic follicles. The cells are characterized by the presence of smooth endoplasmic reticulum, rounded mitochondria with tubular cristae, and abundant, large ( $1.5 \mu \mathrm{m}$ diameter $)$ lipid droplets containing cholesterol and its esters. $3 \beta$-Hydroxysteroid dehydrogenase activity occurs in the interstitial cells. Their ultrastructural characteristics suggest that the cells are not very active, but their abundance and the considerable amount of steroid hormone precursor they contain may compensate for low secretory activity and they may be an important and (from a developmental viewpoint) early source of steroid hormone.
\end{abstract}

Keywords: ovary; interstitial tissue; wood mouse; steroidogenesis

\section{Introduction}

Ovarian interstitial tissue, consisting of specialized cells of a general secretory appearance occurring within the ovarian stroma, has been described for many species of mammal (Brambell, 1956). However, its potential importance in ovarian steroid production is frequently overlooked. The interstitial cells are often the first recognizable steroid-secreting cells in the juvenile ovary (Dawson \& McCabe, 1951; Quattropani, 1973; Hiura et al., 1978). In the adult they constitute the most stable source of steroid production, since the cells are present throughout the reproductive cycle, maintaining their ability to respond to stimulation even after extensive periods of gonadotrophin deprivation (Carithers \& Green, 1972).

In the course of a study of seasonal breeding in the wood mouse (Apodemus sylvaticus) (Clark, 1985 ) it was observed that the ovary contains an unusually large amount of interstitial tissue, and the wood mouse might therefore be suitable for investigation of the origin and significance of interstitial tissue.

\section{Materials and Methods}

Animals. All wood mice were from the laboratory colony maintained in the Department of Agricultural Science, Oxford University. They were housed under a daily photoperiod of $16 \mathrm{~h}$ light at a temperature of $19 \pm 1{ }^{\circ} \mathrm{C}$ in plastic cages $(42 \mathrm{~cm} \times 26 \mathrm{~cm} \times 11 \mathrm{~cm})$, with sawdust, hay and non-absorbent cotton wool for bedding. They were supplied ad libitum with Dixon's Diet $41 \mathrm{~B}$ and water.

Ovaries from 77 females, ranging in age from 5 days to 22 months, were examined, approximately equal numbers being used for routine histology and for histochemical and electron microscopic study. Female wood mice from this colony are sexually mature by the age of about 10 weeks, and remain highly fertile until at least until $2 \frac{1}{2}$ years of age.

*Present address: ICRF Developmental Biology Unit, Department of Zoology, Oxford University, South Parks Road, Oxford OXI 3PS, UK.

$\dagger$ Present address: Department of Zoology, Oxford University, South Parks Road, Oxford OX1 3PS, UK. 
Light microscopy. Animals were killed by ether vapour or cervical dislocation. For routine microscopy procedures ovaries were removed, fixed in Bouin's fluid, embedded in paraffin wax, serially sectioned at $5 \mu \mathrm{m}$ and stained with Ehrlich's haematoxylin and eosin.

For the histochemical studies of lipids, cholesterol and its esters, one ovary from each of 4 sexually mature virgin animals was fixed in $10 \%$ buffered formalin, embedded in gelatine and sections (15 $\mu \mathrm{m}$ prepared with a freezing microtome) were coloured with acetylated Sudan Black (for lipids) and mounted in neutral glycerine jelly, or tested by the Liebermann-Schultz reaction for cholesterol and its esters (Casselman, 1959). For the detection of $3 \beta$-hydroxy-

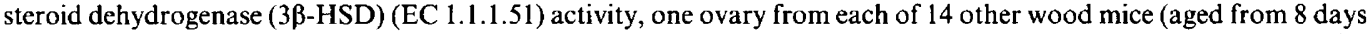
to 22 months) was removed, and placed in a mould containing Tissue-Tek II O.C.T. compound (Miles Laboratories Inc., Naperville, IL, USA). The tissue and its surrounding medium was frozen by immersion in 2-methylbutane previously cooled by suspension in liquid nitrogen. Blocks were stored at $-19^{\circ} \mathrm{C}$ for up to 1 month before use. They were sectioned at $10 \mu \mathrm{m}$ using a cryostat maintained at $-20^{\circ} \mathrm{C}$. Before incubation the sections, attached to glass slides, were placed in cold acetone (at $4^{\circ} \mathrm{C}$ ) for $5 \mathrm{~min}$, followed by two changes of cold phosphate buffer for a total of $5 \mathrm{~min}$ (Deane et al., 1966). The incubation medium contained nitro-blue tetrazolium, nicotinamide adenine dinucleotide $(\mathrm{NAD}+)$, phosphate buffer, potassium cyanide and magnesium chloride (Lojda et al., 1979), and 2 mM-dehydroepiandrosterone (DHA) (Sigma, Poole, Dorset, UK) or $2 \mathrm{mM}$ pregnenolone (Sigma), dissolved in dimethylformamide, were used as substrates. Control incubations were performed without substrate. Sections were incubated for $1 \frac{1}{2} \mathrm{~h}$ at $37^{\circ} \mathrm{C}$. Slides were then rinsed and the sections fixed in $4 \%$ formaldehyde before mounting in neutral glycerine jelly. The distribution of reaction product was noted, and the intensity of reaction graded by eye on a scale of $0-5$. Medium containing nicotinamide adenine dinucleotide, reduced form (NADH), was used to demonstrate the distribution of NADH diaphorase. In all sections diaphorase was distributed throughout the ovary and was not therefore a limiting factor in the localization of $3 \beta-H S D$.

Electron microscopy. Animals were deeply anaesthetized with ether, the abdominal cavity opened and ice-cold $2.5 \%$ glutaraldehyde in $0.1 \mathrm{M}$-sodium cacodylate with $0.1 \mathrm{M}$-sucrose was briefly dripped on to one ovary in situ, which was then quickly removed and cut up, and small pieces of the interstitial tissue were immersed in fresh fixative for 40-60 min. The tissue was then washed in $0 \cdot 1 \mathrm{M}$-sodium cacodylate and sucrose buffer, post-fixed in $1 \%$ osmium tetroxide in $0.1 \mathrm{M}$-sodium cacodylate buffer, and dehydrated through a graded series of alcohols, during which it was stained en bloc in a solution of $0.25 \%$ uranyl acetate in $75 \%$ ethanol. Finally the tissue was embedded in E-mix resin (EMscope Laboratories Ltd, Ashford, Kent TN23 2LN, UK) using propylene oxide as a link reagent.

At the time of removal of the ovary to be examined with the electron microscope, the animal was killed by ether vapour. The other ovary of each animal was prepared for routine light microscopy (see above). For electron microscopy, ultrathin sections were cut (using an LKB III Ultramicrotome) and stained with methanolic uranyl acetate and Reynold's lead citrate. They were examined with an AEI EM 801 transmission electron microscope at $60 \mathrm{kV}$

\section{Results}

\section{Sexually mature virgin wood mice}

In a sexually mature virgin wood mouse, a pair of fresh, unfixed ovaries weighs $6-9 \mathrm{mg}$. An unfixed ovary from such a female comprises translucent follicles and pink corpora lutea separated by extensive white interstitial tissue. In paraffin wax-embedded sections follicles are of different sizes, both healthy and atretic, and the interstitial tissue has a foamy appearance (Fig. 1). The cells of the interstitial tissue are arranged in distinct clumps or lobules, separated by elongated fibroblast-like cells and elements of the vascular system. They are often associated with remnants of atretic follicles. Their nuclei have a characteristic spikey appearance, and the cytoplasm is highly vacuolated (Fig. 2).

Histochemistry. Interstitial cells contain droplets which colour intensely blue with Sudan Black and blue/green in the Liebermann-Schultz reaction.

Formazan deposits resulting from $3 \beta$-HSD activity occurred only in the cytoplasm of interstitial tissue and corpora lutea: granulosa cells, oocytes and interfollicular stromal areas showed no reaction (Fig. 3). Luteal cells exhibited a slightly more intense reaction than interstitial cells. The distribution of reaction product arising from $3 \beta-\mathrm{HSD}$ activity was the same regardless of the substrate utilized. However, the intensity of reaction was in all cases markedly greater in sections incubated with DHA rather than pregnenolone. No reaction product was deposited in sections incubated in the absence of substrate.

Electron microscopy. Interstitial cells contain abundant ovoid inclusions up to $1.5 \mu \mathrm{m}$ in diameter which indent the nucleus and reduce the cytoplasm to comparative insignificance (Fig. 4). 

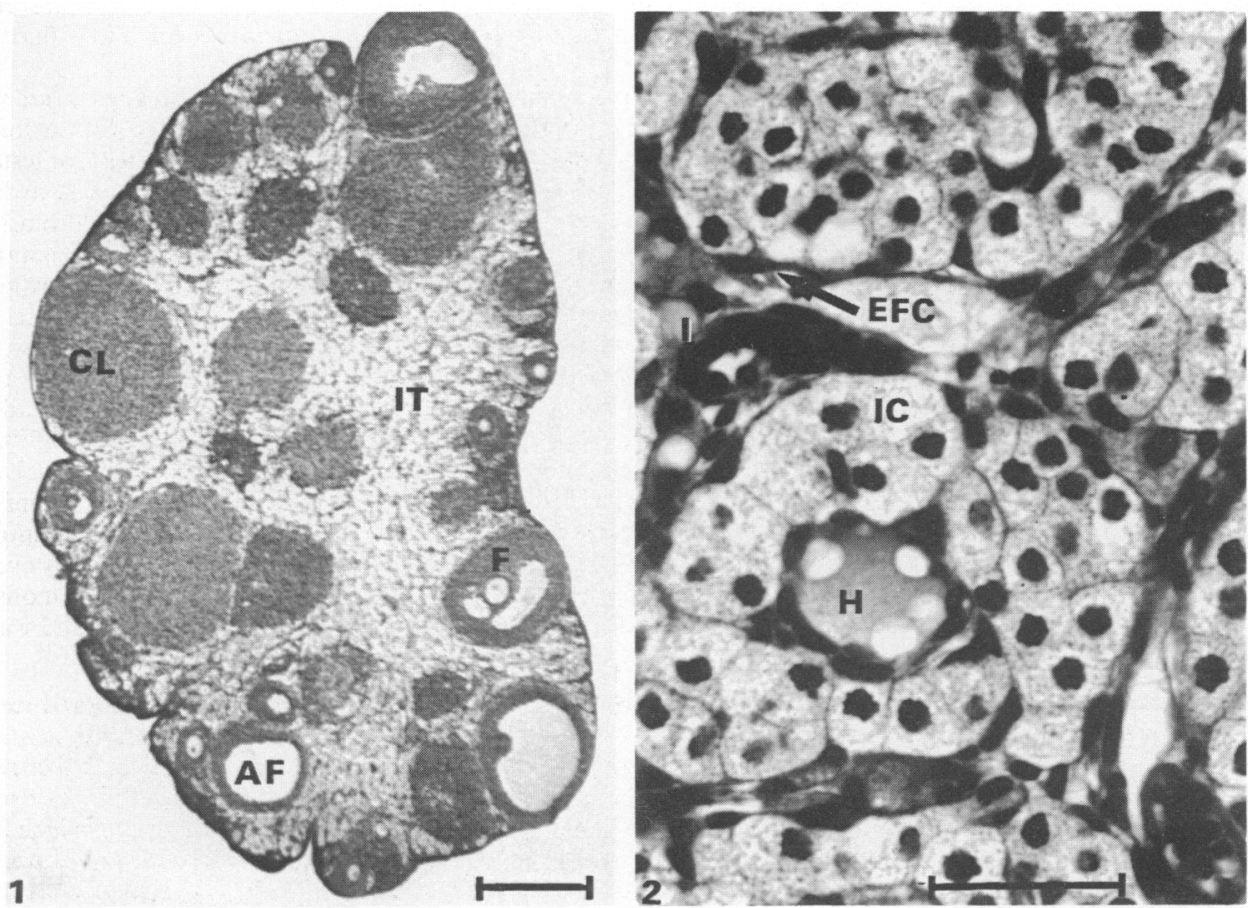

Fig. 1. Cross-section of the ovary of a wood mouse, showing a healthy follicle $(F)$, an atretic follicle (AF), a corpus luteum (CL), and interstitial tissue (IT). Scale bar $=500 \mu \mathrm{m}$.

Fig. 2. Interstitial tissue as seen with the light microscope under high magnification. Interstitial cells (IC) with vacuolated cytoplasm and a spikey nucleus, arranged as lobules and separated by elongated fibroblast-like cells (EFC). $\mathrm{H}=$ 'hole' representing the final remnants of an atretic follicle. Scale bar $=50 \mu \mathrm{m}$.

The inclusions are regular in shape and generally are electron-lucent, although occasional slightly electron-dense inclusions may be seen. The nucleus, indented by the inclusions to give it an irregular shape, contains much heterochromatin arranged as large clumps adjoining the nuclear membrane. The nucleolus is small and rounded, of medium electron density and fine granulosity, often associated with a clump of peripheral heterochromatin (Fig. 4). Mitochondria constitute the most conspicuous cytoplasmic organelles, distributed between the inclusions. They are rounded or occasionally elongated, with tubular cristae situated in an electron-dense matrix, and often contain a dense mitochondrial granule (Fig. 5). The endoplasmic reticulum is generally agranular, consisting of tubules and vesicles ramifying between the inclusions. The lumen of the tubules contains a finely granular material of medium electron density. Ribosomes may be found from place to place attached along part of a tubule (Fig. 5), and also dispersed freely throughout the cytoplasm. The Golgi apparatus is usually located in the perinuclear region, and consists of stacks of lamellae and some dilated cisternae together with vesicles of various sizes. Dense lysosome-like bodies can occasionally be found in the cytoplasm, and sometimes multivesicular bodies are present. A centriole may sometimes be seen positioned close to the nucleus (Fig. 4). The plasma membrane is highly irregular, and is frequently evaginated into microvilli which protrude into the extracellular space. A characteristic feature of the interstitial cells is the presence of numerous vesicles fused with the plasma membrane to form membrane pits, sometimes with an apparent diaphragm across the narrow neck of the opening and often containing a flocculent, slightly electron-dense material (Fig. 5). The majority of these flask-shaped invaginations are smooth-surfaced caveolae, but the 


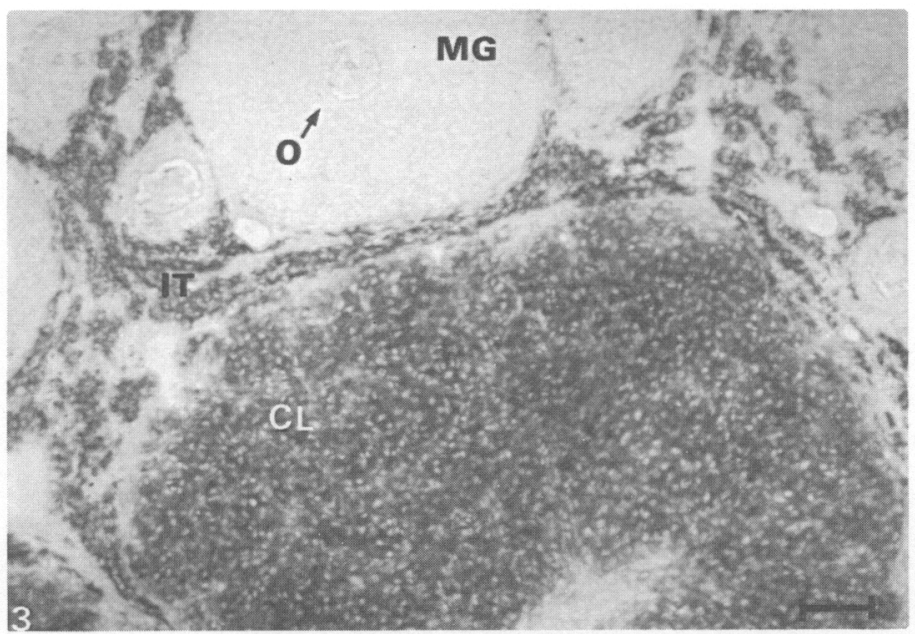

Fig. 3. Localization of $3 \beta-H S D$ activity in the ovary of the adult wood mouse. Formazan deposits resulting from $3 \beta$-HSD activity are located in the interstitial tissue (IT) and corpus luteum (CL). Membrana granulosa (MG) and oocyte (O) of follicles are unstained. Substrate used was DHA. Scale bar $=100 \mu \mathrm{m}$.

membrane of such pits may demonstrate the increased electron-density or 'bristling' associated with coated pits and vesicles. The plasma membranes of adjacent interstitial cells are often closely apposed, but intercellular junctions are rarely seen.

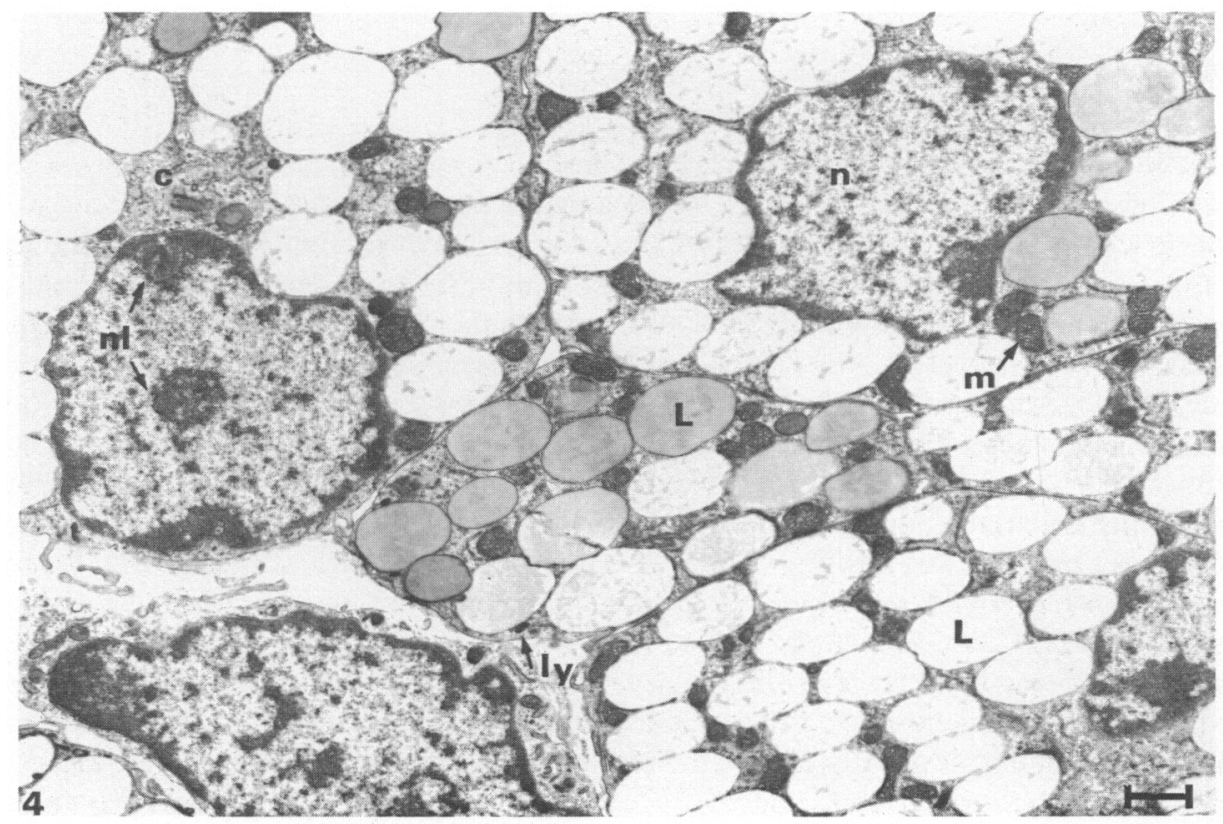

Fig. 4. Fine structure of interstitial cells, showing the nucleus (n) and nucleolus (nl), lipid inclusions (L), mainly electron-lucent but some are electron-dense, and mitochondria $(\mathrm{m})$. An occasional lysosome-like body (ly) may be seen, and a centriole (c) is visible. Scale bar $=1 \mu \mathrm{m}$. 


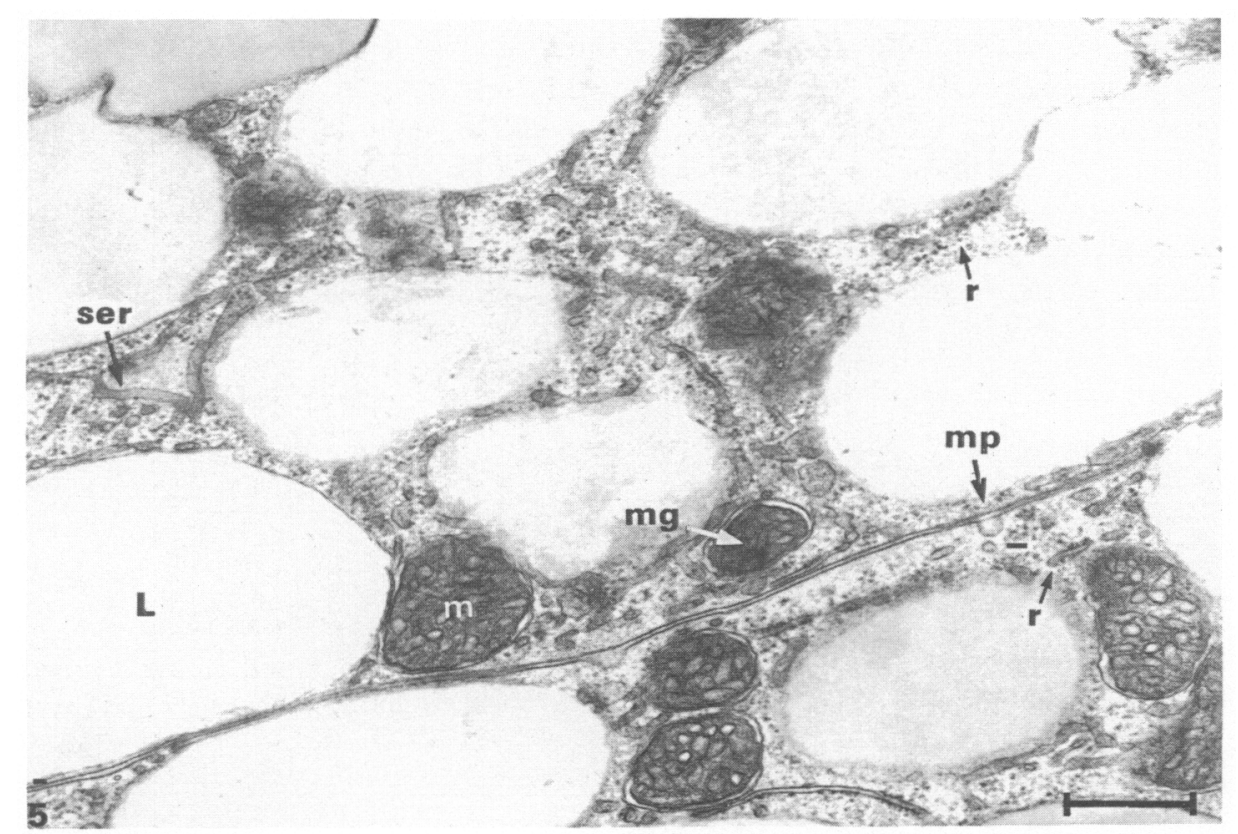

Fig. 5. Detailed ultrastructure of interstitial cells, showing lipid inclusions (L), mitochondria (m) with tubular and vesicular cristae, one mitochondrion containing a granule (mg), and tubules and vesicles of smooth endoplasmic reticulum (ser). Some endoplasmic reticulum has attached ribosomes (r). Other ribosomes are dispersed freely throughout the cytoplasm. A membrane pit (mp) can be seen, with a diaphragm across the neck of the opening. Scale bar $=0.5 \mu \mathrm{m}$.

\section{Juvenile wood mice}

Light microscopy. At 1-2 weeks of age the ovary contains many healthy small and medium sized follicles of types 2-4 in the classification of Pedersen \& Peters (1968). Interfollicular areas at the centre of the ovary appear as a lightly staining meshwork of fibroblast-like elements. By 3 weeks of age, healthy preantral and small antral follicles (types $5 \mathrm{~b}$ and 6 ) are also present. Atretic mediumsized follicles are abundant and an occasional atretic antral follicle may be found. From the age of 4-5 weeks, follicles at all stages of development, excluding Graafian follicles, are present, and atretic antral follicles become considerably more numerous.

Interstitial cells can first be recognized at 22-24 days of age. They appear in the interfollicular stroma as small groups of cells distinguishable from the surrounding stromal elements because of a distinctive cell boundary, cytoplasm which is more eosinophilic, and a rounder, more heterochromatic nucleus. By about 28 days such discrete lobules are more widespread, arising in central regions unassociated with either healthy or atretic follicles (Fig. 6). After a further 5 or 6 days interstitial tissue is considerably more developed and its cells resemble more closely those of the tissue of adults, the cytoplasm becoming more vacuolated and therefore less pink, although the nucleus remains rounded. The most highly developed cells occur in lobules in the central stroma away from follicular components. In the more peripheral areas of the ovary, extensive clusters of smaller interstitial cells whose nuclei are less 'spikey' can be seen surrounding the degenerating fragments of oocytes or zonae pellucidae of atretic follicles. In many cases all that can be seen is a circular space (about $50 \mu \mathrm{m}$ in diameter) around which lobules of interstitial cells are grouped. This presumably represents the site of an atretic follicle (see Fig. 2). Interstitial tissue reaches maximum development at sexual maturity (as judged by perforation of the vagina, which may occur from 10 
weeks onward). By this stage the interstitial cells have enlarged considerably and their nuclei have the 'spikey' appearance typical of fully developed interstitial tissue and the tissue occupies all interfollicular areas (Fig. 1). Animals which, though adult, still have an imperforate vagina (Clarke, 1985) generally have less well-developed interstitial tissue than do wood mice of the same age with a perforate vagina, cells being smaller with nuclei which are less 'spikey'.

Histochemistry. At 8 days of age the reaction for 3 $\beta$-HSD is extremely weak, but over the next 8 days it becomes progressively stronger, localized in increasingly large clusters of cells in the stroma, although neither the distribution nor the intensity of reaction approached that seen in adult wood mice (Fig. 7; Table 1).

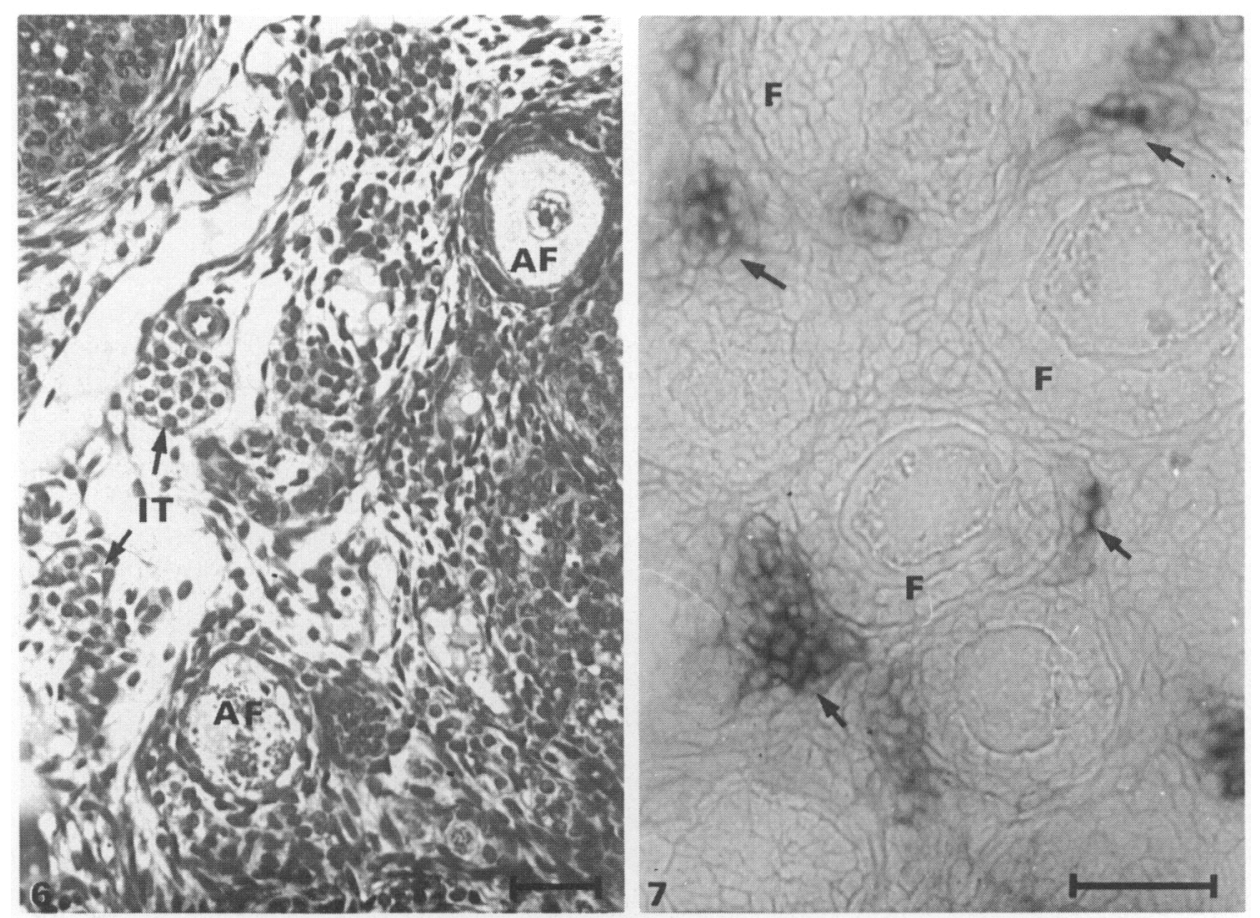

Fig. 6. The ovary of a 27-day-old juvenile wood mouse, showing clusters of interstitial cells (IT) in the stroma and an atretic follicle (AF). Scale bar $=50 \mu \mathrm{m}$.

Fig. 7. The distribution of $3 \beta$-HSD activity in the ovary of a 16-day-old juvenile wood mouse. Formazan deposits (arrowed) are localized in the interfollicular stroma. F, follicles. Scale bar $=50 \mu \mathrm{m}$.

Electron microscopy. Cells exhibiting ultrastructural features characteristic of interstitial cells are first seen at 12 days of age. They occur in the stroma in clusters of 2-3 cells, and are distinguishable from the undifferentiated stromal elements by a rounded nucleus and a greater quantity of more complex cytoplasm which contains lipid inclusions that are small, round and slightly electrondense, and are already numerous, although the cells themselves are relatively small (Fig. 8). Some granular endoplasmic reticulum is present. Small vesicles and tubules of agranular endoplasmic reticulum occur, but are not very abundant. Ribosomes are numerous, scattered throughout the cytoplasm, and are often arranged as polysomes. Rounded mitochondria are abundant, and contain an electron-dense matrix and tubular cristae. Coated vesicles may be occasionally found (Fig. 9). Thereafter the fine structure remains essentially unaltered. By 5 weeks interstitial cells are 
Table 1. Reaction for $3 \beta$-HSD (intensity of staining is graded on a scale of $0-5$ ) within the interfollicular stroma of ovaries from juvenile wood mice

\begin{tabular}{lccccc}
\hline & \multicolumn{5}{c}{ Age } \\
\cline { 2 - 6 } $\begin{array}{l}\text { Incubation } \\
\text { substrate }\end{array}$ & $\begin{array}{c}8 \\
\text { days }\end{array}$ & $\begin{array}{c}12 \\
\text { days }\end{array}$ & $\begin{array}{c}13 \\
\text { days }\end{array}$ & $\begin{array}{c}16 \\
\text { days }\end{array}$ & $\begin{array}{c}11-16 \\
\text { weeks }\end{array}$ \\
\hline DHA & $<0.5$ & $0.5-1$ & 1 & 2 & 4 \\
Pregnenolone & 0 & 0.5 & 0.5 & $1-2$ & 2 \\
\hline
\end{tabular}

larger, more numerous, and arranged in extensive clusters. The cytoplasm is more abundant and contains greater numbers of the above organelles. Further development involves increase in cell size and in the number of inclusions until cells attain the appearance shown in Fig. 4.

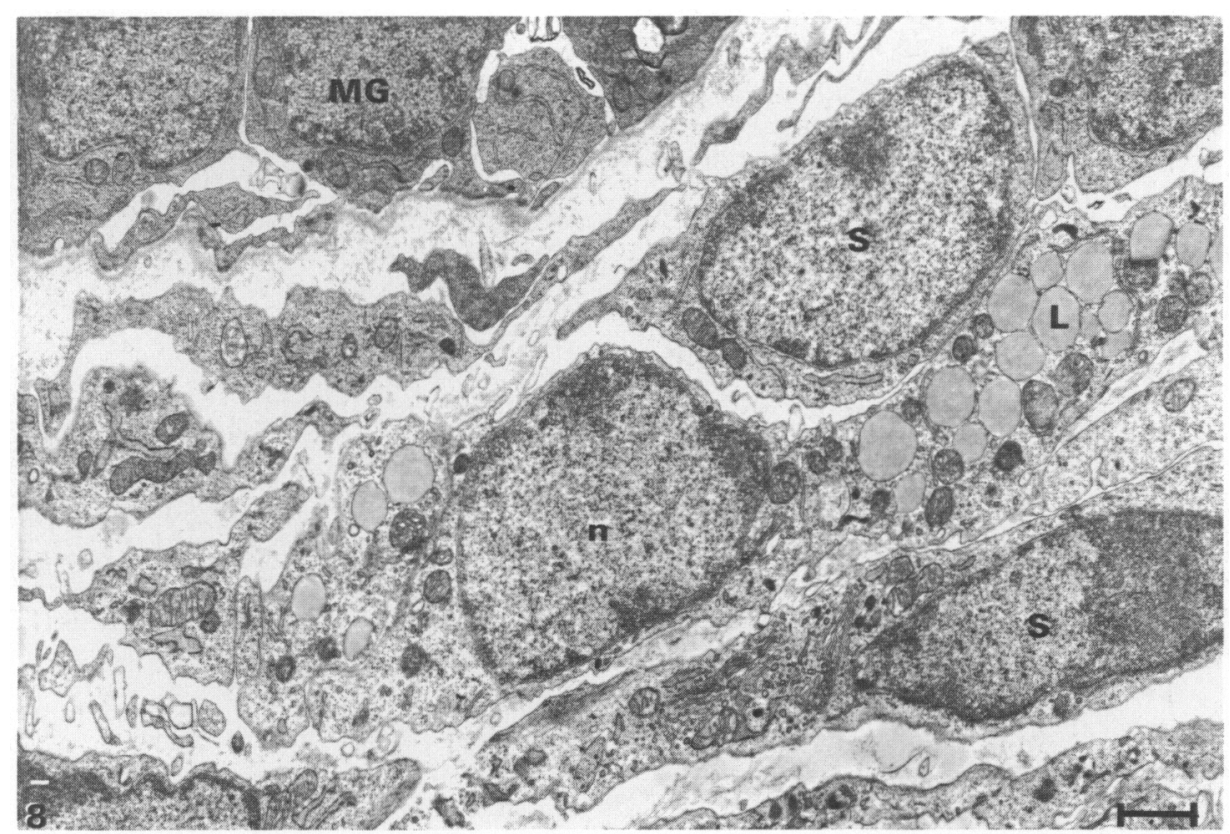

Fig. 8. Interstitial cells in the ovary of a 12-day-old wood mouse. Low-power micrograph to show developing interstitial cells in the interfollicular stroma, nucleus $(\mathrm{n})$, lipid inclusions $(\mathrm{L})$, stroma cell (S), and granulosa cells (MG) of a small follicle. Scale bar $=1 \mu \mathrm{m}$.

During development of the interstitial tissue in juveniles, cells may be found in the stroma which have features in common with both interstitial cells and undifferentiated stroma cells (Fig. 10). Such transitional types contain a small amount of cytoplasm, as do the undifferentiated stroma cells, and also a few round mitochondria with tubular cristae, some vesicles and tubules of smooth membrane together with a few profiles of granular endoplasmic reticulum, and one or more lipid 

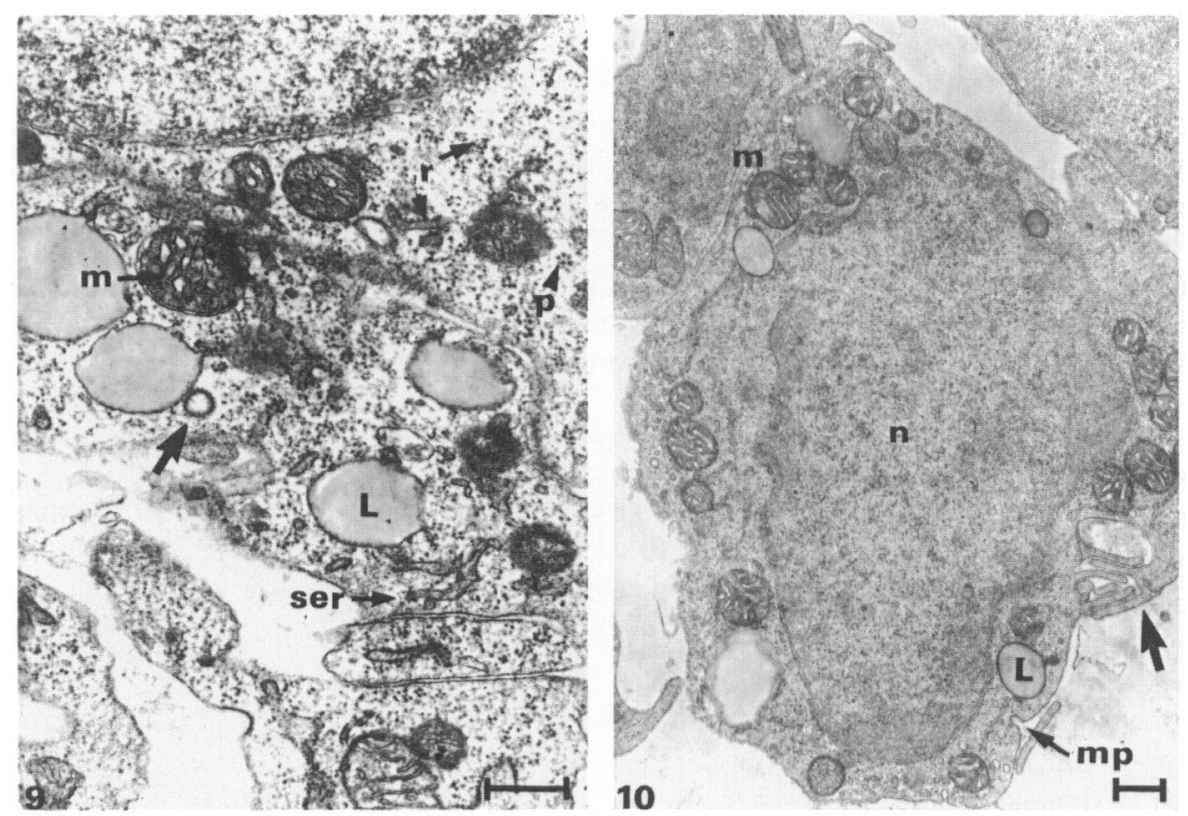

Fig. 9. High-power view of part of interstitial cell in Fig. 8, showing smooth endoplasmic reticulum (ser), ribosomes ( $r$ ), polysomes (p), lipid inclusions (L), mitochondria (m), and a coated vesicle (arrowed). Scale bar $=0.5 \mu \mathrm{m}$.

Fig. 10. Transitional type cell in ovary of 35-day-old juvenile wood mouse. The cell has relatively little cytoplasm, but contains round mitochondria $(\mathrm{m})$ with tubular cristae and a few lipid inclusions (L). $\mathrm{n}$, nucleus, $\mathrm{mp}$, membrane pit. Plasma membrane is evaginated into microvilli (arrowed). Scale bar $=0.5 \mu \mathrm{m}$.

inclusions. The plasma membrane demonstrates a few microvilli and some membrane pits are present. These are all characteristics described in the developing interstitial cell.

\section{Discussion}

The ovarian interstitial tissue of the sexually mature wood mouse is remarkable because it forms such a high proportion of the ovary, and because its cells are packed with droplets which, from their structural and chemical characteristics, are clearly lipoidal, containing cholesterol or its esters. The interstitial tissue also contains at least one enzyme ( $3 \beta$-hydroxysteroid dehydrogenase) involved in the synthesis of progesterone, 17 $\alpha$-hydroxyprogesterone, androstenedione and testosterone (Baillie et al., 1966). Of the mammals most frequently studied, only the rabbit possesses interstitial tissue which is comparable in extent to that of the wood mouse (Davies \& Broadus, 1968; Mori, 1970; Koering \& Scholl, 1978). However, rabbit interstitial tissue is characterized by a greater abundance of mitochondria and of smooth endoplasmic reticulum than is that of the wood mouse, and has far fewer, and smaller, lipid inclusions. Eriksson \& Nyholm (1984) have noted large numbers of lipid droplets in the ovarian interstitial tissue of the yellow-necked mouse, Apodemus flavicollis.

The combination of ultrastructural and histochemical features exhibited by interstitial cells of the wood mouse, namely rounded mitochondria with tubular cristae, smooth rather than granular endoplasmic reticulum, the presence of inclusions containing cholesterol or its esters, and of $3 \beta$-hydroxysteroid dehydrogenase activity, is typically associated with steroid-producing tissue 
(Christensen \& Gillim, 1969; Fawcett et al., 1969). The occurrence of $3 \beta$-hydroxysteroid dehydrogenase has been reported in the interstitial tissue of several species, including rat, mouse, rabbit, guinea-pig, hamster and woman (Baillie et al., 1966).

Although wood mouse interstitial tissue appears to have the potential for steroid production, the occurrence of condensed chromatin, the paucity of smooth endoplasmic reticulum compared with other steroid-secreting cells (e.g. corpus luteum; Parry et al., 1980) and the accumulation of large amounts of lipid suggests that the cells may be relatively inactive. It has been proposed that high lipid content of cells of the corpus luteum reflects a low level of steroid release (Deane et al., 1966; Priedkalns \& Weber, 1968). However, the great abundance of wood mouse interstitial tissue may compensate for a low rate of secretion by individual cells, and the interstitial tissue may be an important source of ovarian steroid hormones.

With the electron microscope, interstitial cells are first distinguishable in the wood mouse ovary during the 2 nd week after birth. At this age the cells have ultrastructural and enzymic characteristics indicative of steroidogenesis, and are therefore the first potentially steroid-producing cells in the ovary, appearing several days before the first large follicles. In 1-week-old rats interstitial cells are distinguishable histochemically and may be responsible for the ability of the juvenile rat ovary to produce oestradiol (Dawson \& McCabe, 1951; Rennels, 1951; Quattropani \& Weisz, 1973; Uilenbroek et al., 1983).

The interstitial tissue of the wood mouse seems to have a dual origin. The earliest interstitial cells to appear in the juvenile ovary, identifiable ultrastructurally or histochemically, arise in the interfollicular stroma unassociated with the follicular elements and at an age when follicular atresia seems not to have commenced. Stages intermediate between stroma and interstitial cells occur. These observations suggest that the interstitial cells develop from undifferentiated stroma cells as in the laboratory mouse (Stegner, 1970; Quattropani, 1973).

At 45 weeks of age there is a marked change in the amount and distribution of wood mouse interstitial tissue. Besides enlarged clusters in the central stroma there are less developed interstitial cells grouped around atretic follicles, suggesting that the cells also arise by differentiation of the theca or granulosa cells of degenerating follicles (see also Eriksson, 1981). Large follicles in particular seem to be involved, as the increase in abundance and change in distribution of the interstitial tissue corresponds to the time of first appearance of large numbers of atretic follicles of type $5 \mathrm{~b}$ and 6. A dual origin of ovarian interstitial tissue was first proposed by Dawson \& McCabe (1951), who noted in the rat that during the 4th week after birth interstitial tissue, besides occurring centrally, began to be found in the outer part of the ovary where follicles with definite thecae had begun to appear. This change takes place shortly after a suggested shift in steroid metabolism of the interstitial cells (Quattropani \& Weisz, 1973). Although the development of the interstitial tissue of the wood mouse closely follows that of the rat, interstitial tissue is very much more abundant in the wood mouse. As in the rat, the shift in the origin and rate of accretion of this tissue about 1 month after birth may signal a change in its steroidogenic activity.

F.A.B. was supported by an S.E.R.C. research studentship. We thank Dr H. M. Charlton, Department of Human Anatomy, Oxford, for the use of a cryostat; Dr B. E. Juniper, Department of Botany, Oxford, for use of the transmission electron microscope; and Valerie Petts, Department of Agricultural Science and Zoology, Oxford, for invaluable technical assistance.

\section{References}

Baillie, A.H., Ferguson, M.M. \& Hart, D.McK. (1966) Developments in Steroid histochemistry. Academic Press, London, New York.

Brambell, F.W.R. (1956) Ovarian changes. In Marshall's Physiology of Reproduction 3rd edn, Vol. 1, Part 1, pp. 397-542. Ed. A. S. Parkes. Longmans Green \& Co., London.

Carithers, J.R. \& Green, J.A. (1972) Ultrastructure of rat ovarian interstitial cells. II: Response to gonadotrophin. J. Ultrastr. Res. 39, 251-261. 
Casselman, W.G.B. (1959) Histochemical Technique. Methuen, London.

Christensen, A.K. \& Gillim, S.W. (1969) The correlation of fine structure and function in steroid-secreting cells, with emphasis on those of the gonads. In The Gonads, pp. 415-488. Ed. K. W. McKerns. North Holland, Amsterdam.

Clarke, J.R. (1985) The reproductive biology of the bank vole (Clethrionomys glareolus) and the wood mouse (Apodemus sylvaticus). Symp. zool. Soc. Lond. 55, 33-59.

Davies, J. \& Broadus, C.D. (1968) Studies on the fine structure of ovarian steroid secreting cells in the rabbit. I. The normal interstitial cells. Am. J. Anat. $123,441-474$.

Dawson, A.B. \& McCabe, M. (1951) The interstitial tissue of the ovary in infantile and juvenile rats. $J$. Morph. 88, 543-571.

Deane, H.W., Hay, M.F., Moor, R.M., Rowson, L.E.A. \& Short, R.V. (1966) The corpus luteum of the sheep: relationships between morphology and function during the oestrous cycle. Acta endocr., Copenh. 51, $245-263$.

Eriksson, M. (1981) The development of the ovary in the wood mouse, Apodemus sylvaticus. Acta morphol. neerl.-scand. 19, 35-40.

Eriksson, M. \& Nyholm, E. (1983) Ultrastructural features of ovarian interstitial tissue in a wild mouse, Apodemus flavicollis, at various reproductive stages, with a note on its histochemistry at the onset of the breeding period. Can. J. Zool. 61, 1560-1567.

Fawcett, D.W., Long, J.A. \& Jones, A.L. (1969) Ultrastructural characteristics of steroid secreting cells. Recent Prog. Horm. Res. 25, 315-368.

Hiura, M., Katsube, Y., Fujii, T. \& Fujiwara, A. (1978) Ultrastructural and cytochemical studies on the cytodifferentiation of the primary interstitial gland in the immature mouse ovary. Hiroshima J. med. Sci. 27, 22 l -226 .
Koering, M.J. \& Scholl, S.A. (1978) Ovarian interstitial gland tissue and serum progestin levels during the first periovulatory period in the mated rabbit. Biol. Reprod. 19, 936-948.

Lojda, Z., Gossrau, R. \& Schiebler, T.H. (1979) Enzyme Histochemistry. A Laboratory Manual. SpringerVerlag, Berlin.

Mori, H. (1970) Fine structure of interstitial gland cells in rabbit ovaries. Med. J. Osaka Univ. 20, 215-233.

Parry, D.M., Willcox, D.L. \& Thorburn, G.D. (1980) Ultrastructural and cytochemical study of the bovine corpus luteum. J. Reprod. Fert. 60, 349-357.

Pedersen, T. \& Peters, H. (1968) Proposal for a classification of oocytes and follicles in the mouse ovary. $J$. Reprod. Fert. 17, 555-557.

Priedkalns, J. \& Weber, A.F. (1968) Ultrastructural studies of the bovine Graafian follicle and corpus luteum. Z. Zellforsch. mikrosk. Anat. 91, 554-573.

Quattropani, S.L. (1973) Morphogenesis of the ovarian interstitial tissue in the neonatal mouse. Anat. Rec. 177, 569-584.

Quattropani, S.L. \& Weisz, J. (1973) Conversion of progesterone to estrone and estradiol in vitro by the ovary of the infantile rat in relation to the development of interstitial tissue. Endocrinology 93, 1269-1276.

Rennels, E.G. (1951) Influence of hormones on the histochemistry of ovarian interstitial tissue in the immature rat. Am. J. Anat. 88, 63-108.

Stegner, H.E. (1970) Electron microscope studies of interstitial tissue in the immature mouse ovary. In Gonadotrophins and Ovarian Development, pp. 232238. Eds W. R. Butt, A. C. Crooke \& M. Ryle. E. \& S. Livingstone, Edinburgh.

Uilenbroek, J.Th.J., Woutersen, P.J.A. \& van der Linden, R. (1983) Steroid production in vitro by rat ovaries during sexual maturation. J. Endocr. 99, 469-475.

Received 9 June 1988 